\title{
Applying a simple model for estimating the likelihood of collision of marine mammals with tidal turbines
}

\author{
Andrea E. Copping ${ }^{\# 1}$, Molly E. Grear ${ }^{\# * 2}$ \\ ${ }^{\#}$ Pacific Northwest National Laboratory \\ Seattle, WA, USA \\ 1andrea.copping@pnnl.gov \\ ${ }^{\circledR}$ University of Washington, School of Marine and Environmental Affairs \\ Seattle, WA, USA \\ *University of Washington, Civil and Environmental Engineering \\ Seattle, WA, USA \\ mgrear@uw.edu
}

\begin{abstract}
As tidal turbine deployments continue at test sites and in commercial areas, the potential risk for injury or death of marine mammals from colliding with rotating turbine blades continues to confound efficient consenting (permitting) of devices. Direct observation of collisions is technically very challenging and costly. Estimates of collision risk to date have been derived from complex collision risk models that depend on estimates of the number of marine mammals found in the area. Using a simple collision model, the risk of collision was examined at three real-world sites, each of which featured an indigenous marine mammal. Two different turbine designs were examined at each site to extend the range of the estimates. The results of the model runs allow for comparison of risk at a range of tidal sites for a variety of the marine mammals thought to be at potential risk.
\end{abstract}

Keywords - Tidal Energy Development, Marine Mammals, Collision Risk Models

\section{INTRODUCTION}

As tidal turbines are deployed at test sites and in commercial areas, the potential risk for injury or death of marine mammals from colliding with rotating turbine blades continues to challenge efficient consenting (permitting) of devices. Because there are few tidal turbines and arrays in the water from which to observe interactions, the risk remains uncertain [1]. Currently, estimates of risk are derived from complex collision risk models that depend on estimates of the number of marine mammals found in the area. The response behaviour of marine mammals to turbines further confounds understanding the risk of collision. In addition, the lack of data collected around operational turbines has hampered validation of the collision risk models.
This paper explores the application of a simple collision risk model for marine mammals interacting with tidal turbines at three potential tidal sites in the US, the UK, and Canada to provide a first-order estimate of the risk of serious injury or death to the animals. The model (previously reported on) was developed to examine the potential probability and consequences of a harbour seal collision with a two-bladed tidal turbine [2]. This paper examines the model applied to two different turbine types at each location using species of indigenous marine mammals for each site. This approach allows us to explore collision risk based on the unique characteristics of the channel and the species of concern. This model focuses on the fate of a single marine mammal traversing a tidal channel with installed tidal turbines. Additional steps are needed to bridge the gap to understanding potential impacts on marine mammal populations.

Marine mammals are often present in tidal channels, where they use the fast-moving flow for transiting the area and for feeding. Harbour seals (Phoca vitulina), harbour porpoises (Phocoena phocoena), and killer whales (Orcinus orca) are observed to use tidal channels, but this behaviour may be somewhat location specific [3][4][5][6]. The marine mammal model applied here considers the swimming speed of the animals, tidal current speed, operating speed and geometry of the turbine, and sets up likely approach scenarios for each marine mammal approaching a turbine. This paper focuses on integrating certain aspects of marine mammal behaviour, as well as the performance of specific tidal devices to understand how different locations may pose distinct risks to the marine mammal populations.

Previous work [7][2][8] explored the potential consequences of a collision between marine mammals and 
turbine blades, and assigned a potential severity of injury. Although difficult to quantify with certainty, the likely severity of injury is also incorporated into the model.

By better understanding the characteristics of tidal channels and specific turbine designs, this simple model can provide insight into the risk to marine mammals from rotating turbine blades. Output from the model can act as a starting point for discussions among tidal developers proposing projects and the appropriate regulators, leading to more efficient permitting of single turbines and arrays.

\section{METHODS}

The elements of the model include the definition of a collision between a marine mammal and a turbine blade; the species of marine mammal chosen; the locations where tidal power development is likely and where a collision might occur; and the design of turbines. We placed three identical turbines in each waterbody to simulate a small tidal array that a marine mammal might encounter.

\section{A. The Collision Risk Model}

The simple model used for this analysis describes the range of possibilities for a marine mammal in a tidal channel where tidal turbines might be placed. A specific series of events must occur for any marine mammal to be injured. Our model defines probabilities for each of these events. To simulate the possible outcomes for a marine mammal travelling through a tidal array, we used a Monte-Carlo simulation to sample the probabilities of each event leading up to a collision.

Scenarios for potential collisions were defined, including those in which a marine mammal would not encounter a turbine blade, the animal would traverse the channel outside of the rotor-swept area, and at times when tidal currents would be slower than the cut-in speed of the turbine.

The scenarios for collisions are defined by the depth at which the marine mammal must be swimming to encounter the turbine. Based on existing literature, the animal is modelled to be at an initial depth based on a probability distribution for U-shaped dives, during which the animal spends most its time near the sea surface or at depth in the water column. This distribution is referred to as the $P_{\text {depth }}$. The animal is assigned a depth based on this distribution, then the model assumes the animal continues to swim at that depth as it passes through the turbine.

The probability of an animal entering the rotor-swept area $\left(P_{\text {rotor }}\right)$ of a turbine blade is described as:

where:

$$
P_{\text {rotor }}=n_{\text {turbines }} \times \frac{A_{\text {rotor }}}{A_{\text {channel }}} \times P_{\text {depth }}
$$

$n_{\text {turbines }}$ represents the number of turbines in the channel;
$A_{\text {rotor }}$ is the swept area of the rotor; and

$A_{\text {channel }}$ is the area of the channel.

The proximity of the marine mammal to the turbine is assigned a binary outcome ( 0 or 1 ) for the probability of being present in the rotor-swept area, and for encountering the blade. The marine mammal can hit the root, middle, or tip of the blade. A probability distribution was created based on the swept area of each of the three blade sections. For example, for a $10 \mathrm{~m}$ radius blade, the tip or outer third of the blade would sweep an area of

$$
A_{t i p}=\pi r^{2}-\pi\left(\frac{2}{3} r\right)^{2}
$$

The blade speed in the model is based on the current speed in the location of interest, the cut-in speed of the turbine, and the maximum rotational speed of the turbine, assuming that higher speeds are likely to cause greater levels of injury to the animal. The cut-in speed chosen for each location and turbine was $0.5 \mathrm{~m} / \mathrm{sec}$, and the maximum speed was capped at 11.8 rpm [9]. Using rotations per minute allows the model to account for the time the animal spends passing through the rotor swept area. Based on the tidal turbine specified in the U.S. Department of Energy (DOE) Reference Model 1 [10] (a current speed of $0.5 \mathrm{~m} / \mathrm{s}$ produces $4 \mathrm{rpm}$ and current speeds of $1.8 \mathrm{~m} / \mathrm{s}$ or greater produce a rotation rate of $11.5 \mathrm{rpm}$ ).

Based on the rate of blade rotation, the probability of the marine mammal encountering the blade $\left(P_{\text {enc }}\right)$ is calculated by determining the area that the blade would sweep in the time it takes for the animal to pass through the swept area:

$$
P_{\text {enc }}=\mathrm{rpm} \times t_{\text {swim }} \times \mathrm{n}_{\text {blades }}
$$

where:

rpm is the rotations per minute of the turbine;

$t_{\text {swim }}$ is the time it takes the marine mammal to swim through the turbine swept area; and

$\mathrm{n}_{\text {blades }}$ is the number of blades on the turbine.

If the value for rpm $\times t_{\text {swim }}$ is greater than one revolution, the animal will always encounter the blade. If the probability of hitting the blade is between one and zero, the probability is sampled by a random number generator to determine whether the marine mammal will collide with the blade, resulting in a final binary distribution ( 0 or 1 ) for encountering the blade.

Based on previous studies, three factors may determine the severity of injury a marine mammal will experience when colliding with a turbine blade: the speed of the turbine blade, the portion of the animal's body where the collision occurs, and the location on the blade that strikes the animal. For each collision in the model, the likelihood of injury to the marine mammal was assigned a 1, 2, or 3 for speeds in the lowest, middle, or fastest third of turbine rotational speeds. The model assigned values of 1,2 , or 3 for the tail, head, and middle of the animal's body, respectively, and a 1,2 , or 3 for the 
location on the blade where a collision might occur at the blade root, middle, or tip, respectively. A severe injury is likely to occur for maximum scores for all three factors: a strike at the tip of the blade, at the fastest speed, and in the middle of the animal's body.

The model was run 1,000,000 times for the three-turbine array with parameters that included the probability of the marine mammal encountering the turbine, the current speed and turbine rotational speed, and the section of the blade and portion of the animal's body that would be involved in a collision. A distribution of the likelihood of injury to a specific animal was generated.

\section{B. Locations Chosen for the Model}

Tidal channels that resemble real-world locations of interest to tidal developers were chosen in the US (Admiralty Inlet, Puget Sound, Washington State), in the UK (Lashy Sound, Scotland), and in Canada (Minas Passage, Bay of Fundy, Nova Scotia). The bathymetric profile of each location was generalised for the model, as were the tidal current speeds and turbine locations. (Figure 1, Table 1).

Admiralty Inlet, USA
Lashy Sound, UK
Minas Passage, Canada

Figure 1. The width and depth of each of the three channels is shown at scale, with three turbines (small dots) evenly spaced across the cross section. Lashy Sound has a much higher blockage than the other deeper, wider channels.

To model the tidal currents, each of the locations was assigned a uniform distribution of velocities between zero (slack tide) and the maximum speed (flood and ebb tide). All tidal currents are reported as a positive flow for both flood and ebb tides.

TABLE 1. THREE LOCATIONS WERE CHOSEN IN THE US, THE UK, AND CANADA AS REASONABLE LOCATIONS FOR TIDAL DEVELOPMENT. BATHYMETRIC AND TIDAL INFORMATION WERE GATHERED FROM INVESTIGATIONS PRIOR TO TIDAL TURBINE DEPLOYMENT IN EACH AREA.

\begin{tabular}{|c|c|c|c|}
\hline Location & $\begin{array}{c}\text { Admiralty } \\
\text { Inlet, Puget } \\
\text { Sound, USA }\end{array}$ & $\begin{array}{l}\text { Lashy Sound, } \\
\text { Scotland, UK }\end{array}$ & $\begin{array}{c}\text { Minas } \\
\text { Passage, Bay } \\
\text { of Fundy, } \\
\text { Canada }\end{array}$ \\
\hline $\begin{array}{l}\text { Channel } \\
\text { depth }\end{array}$ & $55 \mathrm{~m}$ & $30 \mathrm{~m}$ & $60 \mathrm{~m}$ \\
\hline $\begin{array}{l}\text { Channel } \\
\text { width }\end{array}$ & $4000 \mathrm{~m}$ & $1300 \mathrm{~m}$ & $4500 \mathrm{~m}$ \\
\hline
\end{tabular}

\begin{tabular}{|c|c|c|c|}
\hline $\begin{array}{l}\text { Maximum } \\
\text { tidal } \\
\text { currents }\end{array}$ & $3.4 \mathrm{~m} / \mathrm{sec}$ & $\sim 4 \mathrm{~m} / \mathrm{sec}$ & $\begin{array}{l}\sim 5 \mathrm{~m} / \mathrm{sec} \\
13 \mathrm{~m} \text { tidal } \\
\text { range }\end{array}$ \\
\hline
\end{tabular}

\section{Marine Mammal Species}

For each site, a marine mammal was chosen that is indigenous to each location and is under specific protection by national or international legislation and regulation. The southern resident killer whale chosen in Puget Sound is protected as endangered under the U.S. Endangered Species Act; the harbour porpoise represents a stable population in the Canadian Atlantic region; and the harbour seal is protected under the 1970 Conservation of Seals Act in the UK (Figure 2).

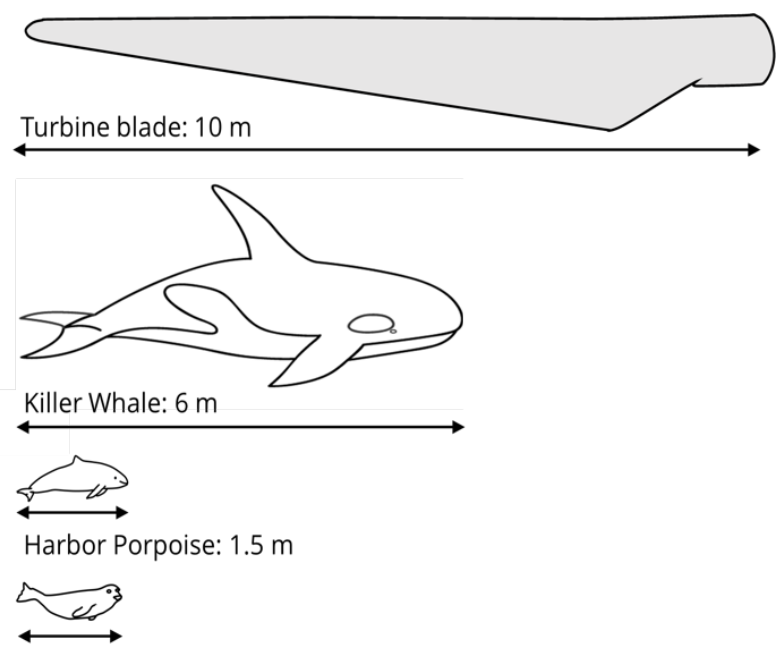

Harbor Seal: 1.4 m

Figure 2. The scale of the tidal blade used in the model is shown in relation to the length of each of the indigenous marine mammals.

Literature values determined the swimming speed and depth profile for each marine mammal, along with movement data in tidal channels, where available (Table 2). For example, data from the San Juan Islands in Washington State suggest that killer whales spend a substantial portion of their time $(>97 \%)$ at the surface. However, killer whales are known to forage in tidal channels, diving to catch their prey [11] For this reason, animal behaviour in tidal channels may be different than that of the animals generally. For the seal, specific dive data for a tidal channel were available [12]. In Lashy Sound, the seals were assumed to spend $25 \%$ of their time in the middle $20 \mathrm{~m}$ of the water column, at the depth of the tidal turbines, based on dive data from other UK tidal channels, and $75 \%$ of their time in the upper $5 \mathrm{~m}$ and within $5 \mathrm{~m}$ of the seabed. In the deeper channels, the harbour porpoise and killer whale were assumed to spend $75 \%$ of their time within $10 \mathrm{~m}$ of the surface and within $10 \mathrm{~m}$ of the seabed. Once an individual animal was assigned a swimming depth distribution, 
the model had each marine mammal species swim at constant depth as it passed through the swept area of the blade.

The swimming speed distributions for the three marine mammals were based on typical swimming speeds. Harbour seals and harbour porpoises have been observed to swim against the prevailing current [13], while killer whales have been observed to swim against the flood tide and with the ebb tide [11]. A distribution of typical animal size (length and girth) for each marine mammal species was also generated for the model. Based on tidal current speeds and swimming speeds, the length of time spent in the rotor-swept area was calculated for each animal, as was the likelihood of the animal being struck on the head, midsection, or tail portions of the body. Based on previous studies, a strike on the animal's midsection is likely to cause the greatest injury because of the greatest momentum transfer from the blade to the animal. A strike in the tail region was assumed to cause the least injury.

TABLE 2. AN INDIGENOUS MARINE MAMMAL WAS CHOSEN FOR EACH TIDAL LOCATION. THE LENGTH, DIVE SPEEDS, AND DIVE PROFILES OF EACH ANIMAL WERE TAKEN FROM THE LITERATURE AND ADDED TO THE MODEL.

\begin{tabular}{|c|c|c|c|}
\hline $\begin{array}{l}\text { Marine } \\
\text { Mammal }\end{array}$ & Killer Whale & $\begin{array}{l}\text { Harbour } \\
\text { Porpoise }\end{array}$ & Harbour Seal \\
\hline $\begin{array}{l}\text { Dive } \\
\text { profile }\end{array}$ & $\begin{array}{l}\text { Presumed to } \\
\text { be U-shaped } \\
\text { dives, with } \\
\text { considerable } \\
\text { time spent } \\
\text { hunting at } \\
\text { depth [14] }\end{array}$ & $\begin{array}{l}\text { U-shaped } \\
\text { dives, mostly } \\
\text { of short } \\
\text { duration (one } \\
\text { minute or } \\
\text { less) [15][16] }\end{array}$ & $\begin{array}{l}\text { U-shaped } \\
\text { dives [12] }\end{array}$ \\
\hline $\begin{array}{l}\text { Average } \\
\text { swimming } \\
\text { Speed }(\mathrm{m} / \mathrm{s})\end{array}$ & $1.7 \pm .1[17]$ & $0.9 \pm 0.3[18]$ & $\begin{array}{l}1.2 \\
{[19]}\end{array}$ \\
\hline $\begin{array}{l}\text { Maximum } \\
\text { swimming } \\
\text { Speed }(\mathrm{m} / \mathrm{s})\end{array}$ & 3.0 [17] & $4.3[18]$ & 2.23 [19] \\
\hline $\begin{array}{l}\text { Average } \\
\text { Length (m) }\end{array}$ & $\begin{array}{l}6.76 \\
\text { (males), } \\
6.01 \\
\text { (females) } \\
\text { [20] }\end{array}$ & $\begin{array}{l}1.45 \text { (males) } \\
1.6 \text { (females) } \\
{[21]}\end{array}$ & $\begin{array}{l}1.42 \text { (males) } \\
1.36 \\
\text { (females) } \\
{[22]}\end{array}$ \\
\hline
\end{tabular}

\section{Tidal turbine specifications}

Two different designs of axial flow turbines-two- and three-blade turbines-were chosen. The technical specifications of the turbines were drawn from the DOE Reference Model [10]. Each blade was $10 \mathrm{~m}$ long with a rotor diameter of $20 \mathrm{~m}$. Each of the three turbines was placed such that the lowest point of the blade sweep was $5 \mathrm{~m}$ above the bottom of the channel, regardless of the channel depth.

\section{RESULTS}

Each model run was independent, providing a data set of $1,000,000$ runs used for statistical analysis for each marine mammal at its associated location in the US, UK, or Canada, for a total of 3,000,00 model runs. Because there are few reliable estimates of the total population of these marine mammal species present at each tidal location, we sampled the data set for the relative portion (percentage) of the marine mammals present at the tidal site. We estimated the relative portion of each population that would encounter a tidal blade, and the likely severity of injury for each encounter.

The severity of injury is reported as injury unlikely, injury possible, injury likely, or serious injury likely (Figure 3). The calculations that lead to "injury unlikely" designation is due to combinations of low-risk factors such as an animal colliding with a slow-moving blade, colliding with the root of the blade, and animals being struck on the tail. Calculations for "injury possible” and "injury likely" designations are derived from a combination of these low-risk factors and higher-risk factors that drive the "serious injury likely" designation including the marine mammal's midsection colliding with the tip of a fastmoving blade.

The model results indicated that 4295 killer whales (out of $1,000,000$ ) were within the rotor-swept area in Admiralty Inlet, representing a collision probability of $0.43 \%$. Less than $0.05 \%$ of the animals in the area were likely to be injured $(0.038 \%$ for the two-bladed turbine and $0.049 \%$ for the three-bladed turbine). For a two-bladed turbine, less than $0.011 \%$ were likely to suffer serious injury and $0.036 \%$ of the animals were unlikely to be injured or could possibly be injured (Table 3, Figure 3).

TABLE 3. FOR EACH TIDAL SITE, THE PROBABILITY OF A MARINE MAMMAL ENTERING THE ROTOR-SWEPT AREA WAS LARGELY DETERMINED BY THE BLOCKAGE OF THE CHANNEL BY THE TURBINE. THE PROPORTION OF ANIMALS COLLIDING WITH A BLADE, AND THE SEVERITY OF INJURY WERE DRIVEN BY UNIQUE PARAMETERS FOR EACH SPECIES. PROBABILITIES ARE SHOWN FOR A MODEL RUN WITH A TWO-BLADED TURBINE IN EACH LOCATION.

\begin{tabular}{lccc}
$\begin{array}{l}\text { Proportion of } \\
\text { Interaction of } \\
\text { animals with } \\
\text { Turbine }\end{array}$ & $\begin{array}{c}\text { Killer } \\
\text { Whale, } \\
\text { Admiralty } \\
\text { Inlet, USA }\end{array}$ & $\begin{array}{c}\text { Harbour } \\
\text { Seal, } \\
\text { Lashy } \\
\text { Sound, UK }\end{array}$ & $\begin{array}{c}\text { Harbour } \\
\text { Porpoise, } \\
\text { Minas } \\
\text { Passage, } \\
\text { Canada }\end{array}$ \\
\hline $\begin{array}{l}\text { Animals in } \\
\text { Swept Area }\end{array}$ & $0.430 \%$ & $2.414 \%$ & $0.343 \%$ \\
$\begin{array}{l}\text { Animals Hit by } \\
\text { Blade }\end{array}$ & $0.073 \%$ & $0.280 \%$ & $0.038 \%$ \\
$\begin{array}{l}\text { Animals With } \\
\text { Severe Injury }\end{array}$ & $0.0107 \%$ & $0.035 \%$ & $0.006 \%$
\end{tabular}


Approximately 24,135 seals encountered the two-bladed turbine after 1,000,000 model runs for Lashy Sound, or 2.414\% of the animals present in the tidal channel. The injury level is once again determined by the encounter variables. A seal hit on the tail by the root of a slow-moving blade was unlikely to be harmed, while a fast-moving blade tip encountering the animal's midsection was likely to cause serious injury. The likelihood of serious injury in Lashy Sound for harbour seals was $0.035 \%$ for the two-bladed turbine, and $0.048 \%$ for the three-bladed turbine (Table 3, Figure 3).

The model predicted the lowest encounter rates and probability of injury for the harbour porpoise in Minas Passage- $0.343 \%$ in the rotor-swept area and serious injury rates of $0.0055 \%$ (Table 3, Figure 3).

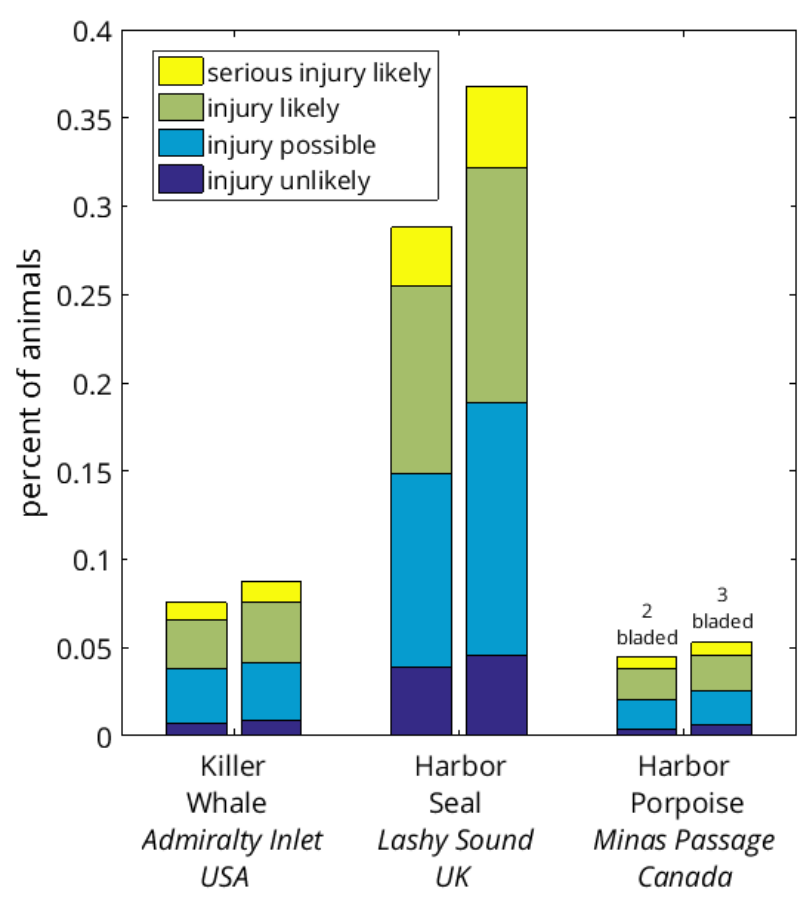

Figure 3. The percentage of marine mammals that will enter the rotor-swept area, for the three tidal channels, is represented by the height of the bars. The left-hand bar represents the two-bladed turbine, while the right-hand bar represents the three-bladed turbine. The likelihood of the level of injury is indicated by the different coloured portions of each bar.

\section{DISCUSSION}

The collision risk model presented here indicates that the proportion of three indigenous species of marine mammals likely to be seriously injured in a collision with a tidal turbine ranges from $0.035 \%$ for harbour seals in the relatively shallow and constricted Lashy Sound to $0.006 \%$ for harbour porpoise and $0.011 \%$ for killer whales in the deeper wider channels in the Bay of Fundy and Puget Sound, respectively. These results support all other evidence collected to date that a collision between a marine mammal and a tidal turbine blade is a rare event [1], even if we do not account for any behavioural avoidance from the animals. The model represented here addresses the risk to individual marine mammals traversing a tidal channel with turbines, but does not address the overall risk to the populations.

The model parameter that drove the greatest differences between the turbine blade encounter rates in the three locations is the relative blockage of the channel. A shallower, more constricted channel with turbine blades of similar size and number posed a higher risk for a marine mammal swimming in the channel. In addition, the swimming speed and length of each marine mammal contributed to the potential severity of injury, if the animal swims within the rotor-swept area. The killer whale in Admiralty Inlet was substantially longer than the other two animals, and consequently spent more time swimming through the rotor-swept area. There is relatively little difference in the likelihood of injury to the marine mammals in any of the locations between the twobladed and three-bladed turbines because the additional blockage from two or three blades does not represent a significant amount of additional time during which an animal would encounter the blade.

These modelled estimates of collision risk represent the likelihood of serious injury for marine mammals that act as passive swimmers with no behavioural response that might further reduce the risk of collision. Marine mammals have excellent sensory capabilities [23] and are expected to be able to detect the presence of tidal devices at some distance. Many marine mammals actively pursuing prey through turbid waters in close proximity to turbines are likely to detect the presence of the turbine, allowing for evasion of the machine. While not yet quantified, it is expected that the behavioural responses of pinnipeds and cetaceans will further lower the probability of collision with a tidal turbine.

The model assumptions that drive estimates of injuries incurred as greater transfers of momentum from a turbine blade to an animal are likely to increase the damage done to the animal. However, it is important to note that the large size difference between the animals examined (the mass of a killer whale can be more than 20 times that of a harbour seal) could also result in considerably more damage done to the smaller animal, if a collision occurs. Based on previous work [7][8], injury to marine mammals is based on biomechanical properties of the skin and blubber layers of the animals, and injury is defined as lacerations and bruising. These measures of injury do not take into account the possibility that the rotational forces of a tidal turbine might cause spinal damage to the skeleton of a smaller animal such as a porpoise or seal. The damage that a tidal turbine might do to the skin of a marine mammal, resulting in abrasions that lead to infection and lingering injury, are also not accounted for, although the skin of pinnipeds (such as the harbour seal) is likely to withstand this type of injury better than that of cetaceans (like the harbour porpoise and killer whale) because the semiterrestrial lifestyle of pinnipeds results in stronger and stiffer skin [24]. 
This modelling effort was set in three basins where tidal development is expected (Admiralty Inlet, Minas Passage, and Lashy Sound). The marine mammals examined are indigenous to each of the three locations, but these species may not prove to be the marine mammals of greatest concern in those locations. It is important to note that the tidal channels examined are crude approximations of the likely deployment locations. Similarly, the axial turbines modelled are based on the theoretical Reference Model turbine [10] which was designed for the DOE as a platform for testing modelling tools and calculating the levelised cost of energy, and they do not represent any existing tidal technology.

Further refinements of the simple model we have presented are possible, especially accounting for tidal turbine arrays that are laid out along channels or in configurations other than the cross-channel placement we have described here. However, the greatest need for better understanding and quantification of collision risk to marine mammals centres around observations of the behaviour of these animals in tidal channels, particularly in the vicinity of deployed and operating turbines. These studies, coupled with monitoring data around early tidal devices and arrays, will help to validate this and other more complex collision risk models, leading to more precise estimates of the probability of marine mammals colliding with tidal turbines, and the potential for serious injury if such collisions occur. A key next step would be to translate the findings of this modelling exercise to population impacts.

The model results presented here are the result of broad approximations of the tidal channels, marine mammal movement and behaviour, and tidal technologies. The model is simple and could easily be modified for use in other tidal channels, with other marine mammal species, and with other tidal turbine designs. The best use of these results, and the application of this model in other locations, would be as a point of departure for discussions between tidal project applicants and the appropriate regulatory and resource management agencies. Discussions between developers and regulators can be informed, we believe, by this first-order estimate of the likely risk of collision by marine mammals, from which more detailed or generalised estimates might be made.

\section{ACKNOWLEDGEMENTS}

The background work that allowed us to do this research depended on the work of many people, and a series of informed discussions with many more. We particularly want to thank Adam Summers and Petra Ditsche at the University of Washington Friday Harbor Laboratories; Rich Jepsen and Chris Chartrand at Sandia National Laboratory; Alicia Gorton at Pacific Northwest National laboratory; Dr. Joe Gaydos at the SeaDoc Society and Jennifer Olson at the San Juan County Marine Mammal Stranding Network; and the Sea Mammal Research Unit team of Carol Sparling, Jason Wood, and Ruth Joy. We are also grateful to the U.S. Department of Energy
(DOE) Water Power Technologies Office for funding preliminary research in this area and the fruitful discussions we have had over time with Jocelyn Brown-Saracino and Samantha Eaves of DOE about the estimation of collision.

\section{REFERENCES}

[1] Copping, A., N. Sather, L. Hanna, J. Whiting, G. Zydlewski, G. Staines, A. Gill, I. Hutchison, A. O'Hagan, T. Simas, J. Bald, C. Sparling, J. Wood, and E. Masden. 2016. Annex IV 2016 State of the Science Report: Environmental Effects of Marine Renewable Energy Development Around the World.

[2] Carlson T., M. Grear, A. Copping, M. Halvorsen, R. Jepsen, and K. Metzinger. 2014. Assessment of Strike of Adult Killer Whales by an OpenHydro Tidal Turbine Blade. PNNL-22041, Pacific Northwest National Laboratory (PNNL), Richland, WA. USA pp. 124.

[3] Wilson B., S. Benjamins S, and J. Elliott. 2013. Using drifting passive echolocation loggers to study harbour porpoises in tidal-stream habitats. Endangered Species Research 22: 125-143.

[4] Zamon, J.E. 2001. Seal predation on salmon and forage fish schools as a function of tidal currents in the San Juan Islands, Washington, USA Fisheries Oceanography 10(4): 353-366.

[5] Hastie, G.D., B. Wilson, P. Thompson. 2003. Fine-scale habitat selection by coastal bottlenose dolphins: application of a new landbased video-montage technique. Canadian Journal of Zoology 81(3): 469-478.

[6] Heimlich-Boran, J.R. 1988. Behavioral ecology of killer whales (Orcinus orca) in the Pacific Northwest. Canadian Journal of Zoology 66(3): 565-578.

[7] Carlson, T.; R. Jepsen; and A. Copping, A. 2013. Potential Effects of the Interaction Between Marine Mammals and Tidal Turbines - An Engineering and Biomechanical Analysis. Paper Presented at the 10th European Wave and Tidal Energy Conference (EWTEC), Aalborg, Denmark.

[8] Copping, A., M. Grear, R. Jepsen, C. Chartrand, and A. Gorton. (in review). Understanding the Potential Risk to Marine Mammals from Collision with Tidal Turbines. Submitted to Int. J. Marine Energy.

[9] Lawson, M.J., Y. Li, and D.C. Sale. 2011. Development and verification of a computational fluid dynamics model of a horizontalaxis tidal current turbine. In Proceedings of the 30th International Conference on Ocean, Offshore, and Arctic Engineering (OMAE 2011), Rotterdam, the Netherlands.

[10] Neary, V.S., M. Previsic, R.A. Jepsen, M.J. Lawson, Y. Yu, A.E Copping, A.A. Fontaine, K.C. Hallett, and D.K. Murray. 2014 Methodology for Design and Economic Analysis of Marine Energy Conversion (MEC) Technologies. Sandia National Laboratories, Albuquerque, NM.

[11] Felleman, F.L., J.R. Heimlich-Boran, and R.W. Osborne. 1991. The feeding ecology of killer whales (Orcinus orca) in the Pacific Northwest. Dolphin Societies: Discoveries and Puzzles (eds. K. Pryor and K.S. Norris), pp. 113-147. University of California Press, Berkeley.

[12] Joy, R., J. Wood, C. Sparling, D.Tollit, A. Copping' and B. McConnell ${ }^{6}$ in review. Empirical measures of harbor seal behavior and avoidance to an operational tidal turbine.

[13] Pierpoint, C. 2008. Harbour porpoise (Phocoena phocoena) foraging strategy at a high energy, near-shore site in south-west Wales, UK. Journal of the Marine Biological Association of the United Kingdom 88(6), 1167-1173.

[14] Baird, R.W., M.B. Hanson, and L.M. Dill. 2005. Factors influencing the diving behaviour of fish-eating killer whales: sex differences and diel and interannual variation in diving rates. Canadian Journal of Zoology 83(2): 257-267.

[15] Westgate, A., A.J. Read, P. Berggren ,H.N. Koopman, and D.E. Gaskin. 1996. Diving behaviour of harbour porpoises, Phocoena phocoena. Oceanographic Literature Review 5(43): 505.

[16] Johnston, D., A.J. Westgate, A.J. Read. 2005. Effects of fine-scale oceanographic features on the distribution and movements of harbour porpoises Phocoena phocoena in the Bay of Fundy. Marine Ecology Progress Series 295: 279-293. 
[17] Williams, R. and D.P. Noren. 2009. Swimming speed, respiration rate, and estimated cost of transport in adult killer whales. Marine Mammal Science 25: 327-350.

[18] Otani, S., Y. Naito, A. Kato, and A. Kawamura. 2000. Diving behavior and swimming speed of a free-ranging harbor porpoise, Phocoena phocoena. Marine Mammal Science 16: 811-814.

[19] Lesage, V., M.O. Hammill, and K.M. Kovacs. 1999. Functional classification of harbor seal (Phoca vitulina) dives using depth profiles, swimming velocity, and an index of foraging success. Canadian Journal of Zoology 77: 74-87

[20] Lockyer, C. 1995. Investigation of aspects of the life history of the harbour porpoise, Phocoena phocoena, in British waters. In: Bjørge, A. and G.P. Donovan (eds.), Biology of the Phocoenids. Report of the International Whaling Commission, Special Issue 16: 189-197.

[21] Durban, J., H. Fearnbach, D. Ellifrit, and K. Balcomb. 2009. Size and body condition of Southern Resident Killer Whales. Contract report to the Northwest Regional Office, National Marine Fisheries Service. Order number AB133F08SE4742, Requisition Number NFFP5000-843300.

[22] Thompson, P.M., D.J. Tollit, S. Enderby, and P.S. Hammond. 1998. The influence of body size and sex on the characteristics of harbour seal foraging trips. Canadian Journal of Zoology 76(6), 1044-1053.

[23] Wartzok, D., and D.R. Ketten. 1999. Marine mammal sensory systems. Biology of Marine Mammals 117-175.

[24] Grear, M.E., P. Ditche, and M.R. Motley. 2017. Development of a Material Constitutive Model for Killer Whale and Harbor Porpoise. In: Proceedings of the Society for Integrative and Comparative Biology Annual Meeting. New Orleans, LA (56: E79-E79). 
